English Language and Literature

stasa.95@hotmail.com

Miljana J. Cvjetićanin

University of Novi Sad

Faculty of Philosophy, Department of

English Studies - M.A. study programme of

English Language and Literature

miljana.c.95@gmail.com

\title{
ANALYSIS OF ACADEMIC SELF-EFFICACY OF EFL STUDENTS IN GRAMMAR SCHOOLS IN SERBIA
}

ABSTRACT: The aim of this research to discover whether there was a connection between the degree of the students' self-efficacy in learning English as a foreign language (EFL), and the participants' attendance of private English lessons, independent use of English outside the classroom, age at which they started learning English, grade achieved at the end of the previous term and self-evaluation of English knowledge. Data was gathered by a survey and analyzed by means of a descriptive and inferential analysis. It was established that overall average self-efficacy is relatively high. Furthermore, independent use of English outside the classroom, students' grade and self-evaluation proved to be the most powerful self-efficacy determinants, leading self-efficacy to be both higher and lower in certain situations. The results imply that the these relationships are complex and it is necessary to offer possible explanations of the results in order to better understand students' needs in EFL learning.

Key words: self-efficacy, EFL students, private English lessons, independent use of English, beginning age of learning English, EFL grade, EFL self-evaluation.

\section{ANALIZA AKADEMSKE SAMOEFIKASNOSTI KOD UČENIKA KOJI UČE ENGLESKI JEZIK KAO STRANI JEZIK U GIMNAZIJAMA U SRBIJI}

APSTRAKT: Cilj ovog istraživanja je da otkrije da li postoji veza između stepena samoefikasnosti učenika koji uče engleski kao strani jezik i pohađanja privatnih časova engleskog jezika, samostalne upotrebe engleskog jezika van učionice, uzrasta od kog uče engleski jezik, ocene iz engleskog jezika ostvarene na kraju prethodnog polugodišta i samoprocene znanja engleskog jezika. Podaci su prikupljeni pomoću upitnika i analizirani korišćenjem deskriptivne $\mathrm{i}$ inferencijalne analize. Utvrđeno je da je sveukupna prosečna samoefikasnost relativno visoka. Pored toga, utvrđeno je i da su samostalna upotreba 
engleskog jezika van učionice, ocena i samoprocena najuticajnije determinante samoefikasnosti, dovodeći do toga da samoefikasnost bude i manja i veća u određenim situacijama. Rezultati upućuju na to da su ovi odnosi kompleksni i da je potrebno ponuditi moguća objašnjenja rezultata kako bi se bolje razumele potrebe učenika u učenju engleskog kao stranog jezika.

Ključne reči: samoefikasnost, učenici koji uče engleski kao strani jezik, privatni časovi engleskog jezika, samostalna upotreba engleskog jezika, uzrast od kog se uči engleski jezik, ocena iz engleskog jezika, samoprocena znanja engleskog jezika.

\section{INTRODUCTION}

In this paper we explore the degree of academic self-efficacy of grammarschool students who learn English as a foreign language (EFL). The aim of this paper is to report on the results of a survey designed to examine the degree of students' self-efficacy in learning English with regard to their attendance of private English lessons, independent use of English outside the classroom, age at which they started learning English, grade achieved at the end of the previous term and self-evaluation of English knowledge. In our research we focused on discovering whether there was a connection between all aforementioned independent variables and the dependent variable, i.e. the students' degree of self-efficacy in learning EFL in their grammar schools, with the aim of determining the significance of possible impacts and whether they positively or negatively influenced self-efficacy. The purpose of this research is to explore these connections and influences in order to gain insight into students' self-efficacy and ways of enhancing it when (and if) necessary, taking students' needs when learning EFL into consideration.

\section{LITERATURE REVIEW}

According to Bandura (1997), people strive to exert control over various aspects of life. This is why their subjective beliefs, in comparison to objective truths, can have a bigger influence on their motivation, affective states and actions (Bandura 1997: 2). When acting upon these beliefs, the beliefs of self-efficacy are crucial, since people are generally more motivated to perform an action which they believe will produce a positive outcome. Therefore, Bandura defines "perceived" self-efficacy as "beliefs in one's own capabilities to organize and execute the courses of action required to produce given attainments" (Bandura 1997: 3).

In an academic setting, it was established that self-efficacy has a great impact on motivation, learning and achievement (Pajares 1996, as cited in Schunk \& Pajares 2007: 15). Namely, students' motivation and self-efficacy are increased when they feel their performance is successful and their set of skills is widening 
(Schunk \& Pajares 2007: 25). Furthermore, it was found that high-school students with high self-efficacy achieved better results and were more persistent than students with lower self-efficacy (Bouffard-Bouchard, Parent \& Larivee 1991, as cited in Schunk \& Pajares 2007: 25). In other words, "academic self-efficacy refers to individuals' convictions that they can successfully perform given academic tasks at designated levels" (Schunk 1991, as cited in Bong \& Skaalvik 2003: 6), influencing academic achievement, especially in college and high-school students (Pajares \& Schunk 2001: 248). Furthermore, Pajares suggests that competence and self-efficacy should be raised through real experiences of success and through an objective interpretation of these experiences (Pajares 2005, as cited in Pajares, Johnson \& Usher 2007: 115; Pajares, Johnson \& Usher 2007: 115).

Concerning attendance of private lessons, Montebon (2016) investigated the effect of shadow education (private tutoring) on students' self-efficacy in science, discovering that students who attend private lessons with tutors generally have a higher level of self-efficacy (Montebon 2016: 38). One of the factors that can enhance students' self-efficacy is social persuasion, i.e. the feedback of private tutors which provides moral and academic support (Pajares \& Britner 2006, as cited in Montebon 2016: 38). Another crucial factor for self-efficacy is students' physiological state, which includes anxiety and level of stress. It is believed that students who attend private lessons experience a lower level of academic stress because of the tutors' support (Pajares \& Britner 2006, as cited in Montebon 2016: $38)$.

Regarding independent use of English outside the classroom, Almarwaey (2017) investigated the consequences of students' use of social networking sites (SNS) in terms of improving their self-efficacy in English. Because of their need to socialize with their colleagues, students would use SNSs for any kinds of questions regarding the course, classes, subject, exam etc., which can encourage learning collaborations among them. They could use SNSs for communication with their professors as well, which could eventually have a positive effect on their selfefficacy level (Almarwaey 2017: 246).

Relating to the age at which students started learning English, Lampert (2007) states that self-efficacy beliefs of children start to affect their future goals while they are very young. Namely, a child showing higher self-efficacy will be more successful academically and will explore more career options, compared to a child with lower self-efficacy (Lampert 2007: 2). However, "through socialization and modeling, people often learn to manage themselves and embrace standards that serve as personal regulators for courses of action in many situations" (Grusec 1992, as cited in Lampert 2007: 3). Therefore, self-efficacy is a dynamic concept which 
can change through an individual's changes of socialization patterns (Lampert 2007: 3).

With regard to the grade the students achieved in the previous term, Wood and Locke (1987) investigated the effect of students' academic self-efficacy and grade goals on their academic performance, establishing that self-efficacy significantly influenced academic performance (Wood \& Locke 1987: 1021), which is in accordance with Bandura's viewpoint that self-efficacy has a direct impact on task performance (Bandura 1982, as cited in Wood \& Locke 1987: 1021). Moreover, Tilfarlioğlu and Cğnkara (2009) investigated self-efficacy of students attending EFL classes and found that self-efficacy had a significant impact on the students' EFL grades at the end of the year, stating that students can benefit from high self-efficacy because this leads to the enhancement of intrinsic motivation, lowering of anxiety, perseverance in difficult tasks, and ultimately to an attainment of wanted outcomes (Tilfarlioğlu and Cğnkara 2009: 136).

With respect to self-evaluation of students' English knowledge, Baleghizadeh and Masoun (2013) noticed that students who had to evaluate themselves more often were more successful in learning English than those who evaluated themselves only once, meaning that self-evaluation positively contributes to the self-efficacy level (Baleghizadeh \& Masoun 2013: 42). It is possible that with self-evaluation students gain more confidence while performing a task which eventually contributes to self-efficacy (Oscarson 1997, as cited in Baleghizadeh \& Masoun 2013: 43).

\section{METHOD}

The aim of this research is to examine whether there is a connection between the students' academic self-efficacy and the participants' attendance of private English lessons, independent use of English outside the classroom, age at which they started learning English, grade achieved at the end of the previous term and self-evaluation of English knowledge. The purpose of this survey is to determine the degree of the students' self-efficacy in learning EFL with respect to the aforementioned independent variables. The cross-sectional survey design was applied, being the simplest and fastest way to collect data among grammar-school students. The surveys were distributed in six classes in two grammar schools in Apatin and Novi Sad, Serbia.

A quantitative research design was used to answer the research question:

Which learner characteristics have independent effect on the students' academic self-efficacy in learning EFL? 
In accordance with the research question, five null hypotheses were formed:

1. There is no difference in the degree of academic self-efficacy regarding attendance of private English lessons.

2. There is no difference in the degree of academic self-efficacy regarding independent use of English outside the classroom.

3. There is no difference in the degree of academic self-efficacy regarding age at which the students started learning English.

4. There is no difference in the degree of academic self-efficacy regarding grade achieved in the previous term.

5. There is no difference in the degree of academic self-efficacy regarding students' self-evaluation.

\subsection{The Population and Participants}

In December 2018, we questioned 101 students enrolled in six classes of two grammar schools in Serbia, ranging from the first year to the fourth year of study. The students were at the average age of 16.6, attending obligatory EFL classes. Concerning the selection process, convenient sampling was applied because only those students who were present in class could complete our surveys, needing about 10 minutes for it. Regarding gender, there were 33 male and 68 female students making the gender patterning uneven. Since EFL classes are conducted in a similar manner in all grammar schools in Serbia, which also generally have uneven gender patterning, we can reason that the sample from our study could be applied to all grammar-school students in Serbia.

\subsection{Instrumentation}

In our study, we used the questionnaire which was constructed by Owen and Froman within their study which "concentrates on the development and estimation of measurement properties of the College Academic Self-Efficacy Scale (CASES)" (Owen \& Froman 1988: 1). The College Academic Self-Efficacy Scale (CASES) was tested both for reliability and validity by Owen and Froman. The authors concluded that the CASES preliminary measurement features were encouraging (Owen \& Froman 1988: 4, 5).

The questionnaire was adapted to our research. Firstly, it was translated from English into Serbian since our participants are generally at the intermediate 
level of English, so we wanted to avoid any possible misunderstandings. Secondly, the students were not asked to write their average grade in English at the given moment, but the grade achieved at the end of the previous term. Finally, four independent variables were added to the survey: attendance of private English lessons, independent use of English outside the classroom, age at which they started learning English and self-evaluation.

Concerning the dependent variable, the participants' degree of academic self-efficacy was tested using 19 statements, which were chosen out of 33 statements from the original survey. The reason for omitting 14 statements was the fact that those statements did not apply to academic self-efficacy in contemporary learning of EFL in Serbia. The participants graded the 19 statements on a Likert scale ranging from 1 to 5 ( 1 being the lowest degree and 5 the highest degree).

\subsection{Variables in the Study}

There are five independent variables in our study. Attendance of private lessons and independent use outside the classroom were inquired by yes/no questions. Age at which they started learning English was an open-ended question. Grade achieved at the end of the previous term and self-evaluation of English knowledge were in the form of the Likert scale question ranging from 1 to 5.

As already mentioned, the dependent variable was examined using 19 statements referring to the degree of the students' self-efficacy in different tasks included in their English lessons in grammar schools. All statements were in the form of a Likert scale question 1-5.

\subsection{Data analysis}

The data was analyzed and the results were obtained by using the statistics package for social science (SPSS), version 20. Descriptive analysis was used in order to extract the mean, range, standard deviation and minimum and maximum scores. Furthermore, inferential analysis was used to analyze an observed pattern in detail. Another reason for using inferential analysis was to determine if the relationship between independent and dependent variables existed and if so, to examine that relationship. Firstly, t-tests were conducted to analyze the effects of the participants' attendance of private lessons and their independent use of English outside the classroom. Secondly, correlations were conducted to test the effects of the age at which participants started learning English, grade achieved at the end of the previous term and self-evaluation. 


\section{RESULTS}

\subsection{Descriptive analysis}

The mean of the average self-efficacy of participants is 3.65 out of the maximum 5 . When dependent variables are observed separately, item 13 shows the highest mean (4.69), while item 16 shows the lowest mean (2.24) (Table 1). Regarding the distribution of items, those in which the statistical score of skewness and/or kurtosis did not exceed three times the value of their standard error were considered to be normally distributed. Meanwhile, those items in which skewness and/or kurtosis exceeded this value were transformed to achieve normal distribution. These include: 1, 2, 3, 4, 7, 10, 11, 12, 13, 14 and 15. Statistical tests for inferential analysis were conducted with the transformed items.

Table 1. Descriptive statistics of dependent variables

$$
\text { Descriptive Statistics }
$$

$$
\text { Std. }
$$

N Minimum Maximum Mean Deviation Skewness Kurtosis

Std. Std.

Statistic Statistic Statistic Statistic Statistic Statistic Error Statistic Error

\begin{tabular}{llllllllll}
\hline 1 & 101 & 1.00 & 5.00 & 3.9208 & 1.33179 & -.993 & .240 & -.248 & .476 \\
\hline 2 & 101 & 1.00 & 5.00 & 3.9109 & 1.28918 & -.945 & .240 & -.308 & .476 \\
\hline 4 & 101 & 1.00 & 5.00 & 3.8020 & 1.40014 & -.821 & .240 & -.664 & .476 \\
\hline 5 & 101 & 1.00 & 5.00 & 4.3267 & 1.12347 & -1.628 & .240 & 1.645 & .476 \\
\hline 6 & 101 & 1.00 & 5.00 & 3.5050 & 1.56604 & -.583 & .240 & -1.213 & .476 \\
\hline 8 & 101 & 1.00 & 5.00 & 3.1584 & 1.49488 & -.167 & .240 & -1.334 & .476 \\
\hline 9 & 101 & 1.00 & 5.00 & 4.0495 & 1.20313 & -1.151 & .240 & .383 & .476 \\
\hline 10 & 101 & 1.00 & 5.00 & 3.0594 & 1.45480 & -.105 & .240 & -1.331 & .476 \\
\hline 11 & 101 & 1.00 & 5.00 & 3.5941 & 1.42953 & -.591 & .240 & -.943 & .476 \\
\hline 12 & 101 & 1.00 & 5.00 & 4.2772 & 1.03072 & -1.197 & .240 & .322 & .476 \\
\hline 13 & 101 & 1.00 & 5.00 & 3.8812 & 1.21068 & -.906 & .240 & -.123 & .476 \\
\hline 14 & 101 & 1.00 & 5.00 & 4.3564 & 1.01572 & -1.644 & .240 & 2.181 & .476 \\
\hline 15 & 101 & 1.00 & 5.00 & 4.6931 & .73134 & -2.734 & .240 & 8.013 & .476 \\
\hline 16 & 101 & 1.00 & 5.00 & 3.7921 & 1.45820 & -.854 & .240 & -.739 & .476 \\
\hline 17 & 101 & 1.00 & 5.00 & 4.4059 & .98161 & -1.802 & .240 & 2.653 & .476 \\
\hline 18 & 101 & 1.00 & 5.00 & 2.2376 & 1.45704 & .743 & .240 & -.907 & .476 \\
\hline 19 & 101 & 1.00 & 5.00 & 2.8614 & 1.46990 & .283 & .240 & -1.286 & .476 \\
\hline Average & 101 & 1.00 & 5.00 & 3.1881 & 1.50806 & -.167 & .240 & -1.374 & .476 \\
\hline Valid N & 101 & 1.00 & 5.00 & 2.3861 & 1.46267 & .611 & .240 & -1.037 & .476 \\
\hline (listwise) & 1.47 & 5.00 & 3.6529 & .75757 & -.615 & .240 & .134 & .476 \\
\hline & & & & & & & & & \\
\hline & & & & & & & & & \\
\hline
\end{tabular}




\subsection{Inferential analysis}

\subsubsection{Attendance of private English lessons}

Firstly, Table 2. shows that the statistically significant items were: $5(\mathrm{t}=-$ $2.100, \mathrm{p}=0.038), 10(\mathrm{t}=3.642, \mathrm{p}=0.000), 15(\mathrm{t}=-2.562, \mathrm{p}=0.012)$. Secondly, Table 2. also shows group statistics which was used to determine the difference in mean scores of participants who attend and do not attend private English lessons. Positive and negative t-coefficients are interpreted equally since both rebut the null hypothesis that there is no difference in the degree of academic self-efficacy, and the higher the t-coefficient is, the more significant the item is.

Table 2. Group statistics and Independent Samples Test for attendance of private English lessons

\begin{tabular}{|c|c|c|c|c|c|c|}
\hline \multirow{2}{*}{\multicolumn{4}{|c|}{ Group statistics }} & \multirow{2}{*}{\multicolumn{3}{|c|}{$\begin{array}{l}\text { Independent Samples Test } \\
\text { t-test for Equality of Means }\end{array}$}} \\
\hline & & & & & & \\
\hline \multicolumn{2}{|c|}{ Private Lessons } & Mean & $\begin{array}{c}\text { Std. } \\
\text { Deviation }\end{array}$ & $\mathrm{t}$ & $\begin{array}{l}\text { Sig. (2- } \\
\text { tailed) }\end{array}$ & $\begin{array}{c}\text { Mean } \\
\text { Difference }\end{array}$ \\
\hline \multirow[t]{2}{*}{5} & no & 3.2958 & 1.58920 & -2.100 & .038 & -.70423 \\
\hline & yes & 4.0000 & 1.41421 & -2.202 & .031 & -.70423 \\
\hline \multirow[t]{2}{*}{10} & no & .2149 & .23977 & 3.051 & .003 & .14464 \\
\hline & yes & .0702 & .15172 & 3.642 & .000 & .14464 \\
\hline \multirow[t]{2}{*}{15} & no & .6109 & .15831 & -1.844 & .068 & -.05481 \\
\hline & yes & .6657 & .05608 & -2.562 & .012 & -.05481 \\
\hline
\end{tabular}

\subsubsection{Independent use of English outside the classroom}

Firstly, Table 3. shows that the statistically significant items were: $2(t=$ 3.944, $\mathrm{p}=0.000), 3(\mathrm{t}=3.44, \mathrm{p}=0.001), 4(\mathrm{t}=3.412, \mathrm{p}=0.001), 5(\mathrm{t}=-5.067, \mathrm{p}=$ 0.000), $6(\mathrm{t}=-6.774, \mathrm{p}=0.000), 7(\mathrm{t}=2.435, \mathrm{p}=0.017), 8(\mathrm{t}=-7.357, \mathrm{p}=0.000)$, $10(\mathrm{t}=4.487, \mathrm{p}=0.000), 11(\mathrm{t}=3.411, \mathrm{p}=0.001), 15(\mathrm{t}=-4.167, \mathrm{p}=0.001), 17(\mathrm{t}$ $=-3.187, \mathrm{p}=0.003), 18(\mathrm{t}=-2.212, \mathrm{p}=0.029)$. Secondly, Table 3. also shows group statistics which was used to determine the difference in mean scores of participants who use and do not use English independently outside the classroom. Positive and negative t-coefficients are interpreted equally since both rebut the null hypothesis that there is no difference in the degree of academic self-efficacy, and the higher the t-coefficient is, the more significant the item is. 
Table 3. Group statistics and Independent Samples Test the independent use of English outside the classroom

\begin{tabular}{|c|c|c|c|c|c|c|}
\hline \multicolumn{4}{|c|}{ Group Statistics } & \multicolumn{3}{|c|}{$\begin{array}{l}\text { Independent Samples Test } \\
\text { t-test for Equality of Means }\end{array}$} \\
\hline \multicolumn{2}{|c|}{ Independent Use } & Mean & $\begin{array}{c}\text { Std. } \\
\text { Deviation }\end{array}$ & $\mathrm{t}$ & $\begin{array}{l}\text { Sig. }(2- \\
\text { tailed) }\end{array}$ & $\begin{array}{c}\text { Mean } \\
\text { Difference }\end{array}$ \\
\hline \multirow[t]{2}{*}{2} & no & .4584 & .26233 & 3.944 & .000 & .25479 \\
\hline & yes & .2036 & .23229 & 3.627 & .002 & .25479 \\
\hline \multirow[t]{2}{*}{3} & no & .4595 & .27461 & 3.440 & .001 & .23972 \\
\hline & yes & .2198 & .25214 & 3.244 & .004 & .23972 \\
\hline \multirow[t]{2}{*}{4} & no & .3241 & .24261 & 3.412 & .001 & .20406 \\
\hline & yes & .1201 & .21504 & 3.140 & .005 & .20406 \\
\hline \multirow[t]{2}{*}{5} & no & 1.8750 & 1.14746 & -5.067 & .000 & -1.93676 \\
\hline & yes & 3.8118 & 1.44333 & -5.926 & .000 & -1.93676 \\
\hline \multirow[t]{2}{*}{6} & no & 1.6250 & .88506 & -4.976 & .000 & -1.82206 \\
\hline & yes & 3.4471 & 1.41005 & -6.774 & .000 & -1.82206 \\
\hline \multirow[t]{2}{*}{7} & no & .3511 & .24174 & 2.435 & .017 & .15764 \\
\hline & yes & .1935 & .23683 & 2.401 & .026 & .15764 \\
\hline \multirow[t]{2}{*}{8} & no & 1.5000 & .81650 & -5.260 & .000 & -1.85294 \\
\hline & yes & 3.3529 & 1.36020 & -7.357 & .000 & -1.85294 \\
\hline \multirow[t]{2}{*}{10} & no & .3855 & .25978 & 4.487 & .000 & .25383 \\
\hline & yes & .1317 & .19679 & 3.713 & .002 & .25383 \\
\hline \multirow[t]{2}{*}{11} & no & .4385 & .22359 & 3.411 & .001 & .21334 \\
\hline & yes & .2251 & .23059 & 3.484 & .002 & .21334 \\
\hline \multirow[t]{2}{*}{15} & no & .4275 & .22589 & -8.078 & .000 & -.23732 \\
\hline & yes & .6648 & .06772 & -4.167 & .001 & -.23732 \\
\hline \multirow[t]{2}{*}{17} & no & 2.0625 & .99791 & -2.427 & .017 & -.94926 \\
\hline & yes & 3.0118 & 1.49995 & -3.187 & .003 & -.94926 \\
\hline \multirow[t]{2}{*}{18} & no & 2.4375 & 1.59034 & -2.212 & .029 & -.89191 \\
\hline & yes & 3.3294 & 1.45887 & -2.084 & .050 & -.89191 \\
\hline
\end{tabular}

\subsubsection{Age at which participants started learning English, grade achieved at the} end of the previous term and self-evaluation of English knowledge

Table 4. was used to identify statistically significant items. Regarding age at which participants started learning English, those include 6 and 8. Both items show negative correlation, meaning that the lower the age at which students started learning English, the higher the degree of self-efficacy, and vice versa. The results also show that item 6 exhibits moderate correlation, while item 8 exhibits weak correlation meaning that item 6 has a stronger relationship to the independent variable of the beginning age of learning. 
Table 4. Correlations between dependent variables and age at which participants started learning English, grade achieved at the end of the previous term and self-evaluation of English knowledge

\begin{tabular}{|c|c|c|c|c|}
\hline \multicolumn{5}{|c|}{ Correlations } \\
\hline & & $\begin{array}{l}\text { Beginning Of } \\
\text { Learning }\end{array}$ & Grade & Self-evaluation \\
\hline \multirow[t]{2}{*}{2} & Pearson Correlation & .096 & $-.566^{* *}$ & $-.580^{* *}$ \\
\hline & Sig. (2-tailed) & .341 & .000 & .000 \\
\hline \multirow[t]{2}{*}{3} & Pearson Correlation & .157 & $-.472^{* *}$ & $-.525^{* *}$ \\
\hline & Sig. (2-tailed) & .116 & .000 & .000 \\
\hline \multirow[t]{2}{*}{4} & Pearson Correlation & .194 & $-.454^{* *}$ & $-.517^{* *}$ \\
\hline & Sig. (2-tailed) & .051 & .000 & .000 \\
\hline \multirow[t]{2}{*}{5} & Pearson Correlation & -.186 & $.511^{* * *}$ & $.608^{* * *}$ \\
\hline & Sig. (2-tailed) & .063 & .000 & .000 \\
\hline \multirow[t]{2}{*}{6} & Pearson Correlation & $-.362^{* *}$ & $.481^{* * *}$ & $.546^{* *}$ \\
\hline & Sig. (2-tailed) & .000 & .000 & .000 \\
\hline \multirow[t]{2}{*}{7} & Pearson Correlation & -.006 & $-.220^{*}$ & $-.340^{* *}$ \\
\hline & Sig. (2-tailed) & .953 & .027 & .001 \\
\hline \multirow[t]{2}{*}{8} & Pearson Correlation & $-.210^{*}$ & $.470^{* * *}$ & $.519^{* *}$ \\
\hline & Sig. (2-tailed) & .035 & .000 & .000 \\
\hline \multirow[t]{2}{*}{10} & Pearson Correlation & .188 & $-.723^{* *}$ & $-.728^{* *}$ \\
\hline & Sig. (2-tailed) & .059 & .000 & .000 \\
\hline \multirow[t]{2}{*}{11} & Pearson Correlation & .042 & $-.332^{* * *}$ & $-.464^{* *}$ \\
\hline & Sig. (2-tailed) & .680 & .001 & .000 \\
\hline \multirow[t]{2}{*}{12} & Pearson Correlation & .018 & -.132 & $-.225^{*}$ \\
\hline & Sig. (2-tailed) & .855 & .189 & .024 \\
\hline \multirow[t]{2}{*}{14} & Pearson Correlation & .055 & $-.265^{* *}$ & $-.223^{*}$ \\
\hline & Sig. (2-tailed) & .584 & .007 & .025 \\
\hline \multirow[t]{2}{*}{15} & Pearson Correlation & -.172 & $.592^{* *}$ & $.794^{* *}$ \\
\hline & Sig. (2-tailed) & .086 & .000 & .000 \\
\hline \multirow[t]{2}{*}{16} & Pearson Correlation & -.039 & $.253^{*}$ & $.247^{*}$ \\
\hline & Sig. (2-tailed) & .701 & .011 & .013 \\
\hline \multirow[t]{2}{*}{17} & Pearson Correlation & -.144 & $.218^{*}$ & $.241^{*}$ \\
\hline & Sig. (2-tailed) & .150 & .028 & .015 \\
\hline \multirow[t]{2}{*}{19} & Pearson Correlation & .012 & .186 & $.222^{*}$ \\
\hline & Sig. (2-tailed) & .908 & .062 & .026 \\
\hline
\end{tabular}

Regarding the grade achieved at the end of the previous term, statistically significant items include: $2,3,4,5,6,7,8,10,11,14,15,16,17$. Items 5, 6, 8, 15 , 16,17 show positive correlation, meaning that the higher the grade, the higher the degree of self-efficacy, while items $2,3,4,7,10,11,14$ show negative correlation meaning that the lower the grade, the higher the degree of self-efficacy (and vice 
versa). Furthermore, item 10 exhibits strong correlation, items 2, 3, 4, 5, 6, 8, 11 and 15 exhibit moderate correlation, and items 7, 14, 16 and 17 exhibit weak correlation, showing the strength of relationships between certain items and the independent variable of grade.

Regarding the self-evaluation of English knowledge, statistically significant items include: $2,3,4,5,6,7,8,10,11,12,14,15,16,17,19$. Items 5 , $6,8,15,16,17,19$ show positive correlation, meaning that the higher the selfevaluation, the higher the degree of self-efficacy, while items $2,3,4,7,10,11,12$, 14 show negative correlation, meaning that the lower the self-evaluation, the higher the degree of self-efficacy (and vice versa). Furthermore, items 10 and 15 exhibit strong correlation, items $2,3,4,5,6,7,8$ and 11 exhibit moderate correlation, and items 12, 14, 16, 17 and 19 exhibit weak correlation, showing the strength of relationships between certain items and the independent variable of self-evaluation.

\section{DISCUSSION}

The aim of this research was to examine whether there is a connection between the students' academic self-efficacy and the participants' attendance of private English lessons, independent use of English outside the classroom, age at which they started learning English, grade achieved at the end of the previous term and self-evaluation of English knowledge, thus trying to determine which learner characteristics have independent effect on the students' self-efficacy in learning EFL.

Descriptive statistics showed that the mean of the average self-efficacy of participants was 3.65 , indicating that the students have a relatively high degree of academic self-efficacy. The students showed the highest degree of self-efficacy in item 13 (I attend classes regularly). A possible explanation could be that the attendance in class alone does not always demand any active participation and challenging of motivation, anxiety or other affective factors, so the students generally do not avoid coming to classes.

On the other hand, the students showed the lowest degree of self-efficacy in item 16 (I talk to my teacher privately in order get to know them better). It is likely that most students do not feel that they should meet their teachers on a personal level because they might think their teachers are not interesting or because they think their relationship should remain only professional.

When it comes to the attendance of private lessons, three items proved to be statistically significant. First of all, the students who attend private English lessons feel more confident in taking tests which require long and argumentative 
responses (item 5), probably because they spend more time learning English and practising all of the language skills, which eventually prepares them better for this type of tests. Furthermore, students who attend private lessons might be exposed to assessment which includes essay questions since the learning groups are smaller than in grammar-school classes and teachers have more time to implement different types of evaluation. Secondly, those students who attend private lessons may understand all content discussed in class more clearly than those who do not (item 15). It is possible that this happens because they are more exposed to English than the students who only learn English in school, which might lead to better understanding. However, the results also revealed that the students who do not attend private English lessons estimate their grades as higher (item 10). It could be assumed that those students who attend private classes are more aware of their knowledge and how much there is still to be learned. On the other hand, the students who do not attend private English lessons may think they are at the higher level only because they are not aware of their shortcomings. Additionally, it is possible that the students who attend private English lessons got a couple of bad grades on tests in private schools which led them to doubt their knowledge. It can be concluded that students who attend private lessons are more successful in producing complex answers to broader questions and in understanding the content probably because the additional exposure to language enhances their selfconfidence. However, this does not necessarily mean that students attending private lessons believe that they would get a good grade, possibly because they are more aware of the complexity of language. Another reason could be that language is more often tested via objective tests, which are more focused on specific units rather than general content and understanding.

When the independent use of English outside the classroom is concerned, there is a difference in items: 2, 3, 4, 5, 6, 7, 8, 10, 11, 15, 17 and 18. Regarding items 2 and 3 which include taking part in discussions and speaking before teachers and classmates, students who use English independently showed lower selfefficacy, probably because they feel threatened by the classroom environment and are unable to relax like they can when they communicate outside school. Regarding items 4 and 10, which include taking objective tests (mostly used for grading) and getting good grades, self-efficacy is again stronger in students who do not use English independently, confirming that students who are relaxed outside the classroom feel anxious inside it and are often not confident in taking formal tests. Furthermore, objective tests and grading in grammar schools is often aimed at assessing knowledge of specific language units, while everyday use is more focused on understanding the general content and ability to transfer ideas. Finally, 
considering items 7 and 11, which include listening carefully in order to understand complex topics and studying to master the content completely, students who do not use English independently showed higher self-efficacy. It is possible that they are more confident because their main concern is completing a task and getting a good grade, rather than understanding whole content and complex units, so they do not really get into the depth of lectures.

However, students who use English independently outside school showed greater self-efficacy in items 5, 6 and 8, which include argumentation and completing complex tasks such as writing a paper or answering essay questions, and tutoring other students. It is possible that authentic language use has enabled them to tackle complex assignments and tasks, as well as enhanced their confidence to help others. Furthermore, these students are more confident in items 15 and 17, which include understanding the content and relating it to other subjects, possibly because they are more confident since they are exposed to other aspects of language which are not covered in school. Finally, these students also show greater self-efficacy when having to stand up to a teacher (item 18), probably because their awareness that they can use English without the teacher's help gives them confidence to also question teachers' opinions. It could be concluded that students who use English in everyday life outside school are more self-efficient in understanding the content on the whole by relating it to authentic use, also being able to connect their language knowledge to the wider knowledge from other courses and everyday situations. However, self-efficacy is lower when they are faced with forms of classroom assessment or speaking since they are probably not comfortable in these formal situations.

Regarding the age at which participants started learning English, students who started learning early showed higher self-efficacy in items 6 and 8, meaning that they are more self-confident when they write seminar papers and tutor other students, maybe because they have positive experiences from longer exposure to learning. It could be also assumed that they have been more often exposed to more complex tasks such as writing papers, making this type of task familiar to them. Longer contact with the language also might make them more likely to tutor other students because they have a longer experience of the language and perhaps a better understanding which provides them with higher self-esteem.

Regarding the grade achieved at the end of the previous term and selfevaluation, results are very similar. Students who get higher grades exhibit higher self-efficacy in items $5,6,8,15,16$ and 17 , while students who grade themselves highly exhibit high self-efficacy in items 5, 6, 8, 15, 16, 17 and 19. This shows that students who get high grades and assess their knowledge of English higher are also 
confident both in doing essay questions and writing seminar papers (items 5 and 6). Furthermore, they are confident in tutoring other students (item 8) and in understanding content in classes and relating that content to other subjects (items 15 and 17). Additionally, they are also eager to talk to their teachers and find out more about them (item 16). All of this could be explained by the fact that students' self-confidence is often raised by good grades, which can make students more proficient in writing and argumentation and in tutoring others. Moreover, good grades may lead them to love the subject, encouraging them to master the content and talk more with teachers. Also, it is possible that high self-efficacy leads to the achievement of better grades which, in turn, leads to further enhancement of selfefficacy. Additionally, students with high self-evaluation are prone to studying regularly rather than cramming (item 19) and they probably feel more confident because they know they have studied on a regular basis, or their self-efficacy, in turn, makes them willing to study regularly.

However, students with lower grades reported greater self-efficacy (or vice versa) in the following items: 2, 3, 4, 7, 10, 11 and 14. Similarly, students who assessed themselves with lower grades reported greater self-efficacy (or vice versa) in the following items: 2, 3, 4, 7, 10, 11, 12 and 14. Even though some students have high grades and self-assessment, they are not willing to engage in speaking exercises, which include class discussions or answering questions in front of other classmates (items 2 and 3), probably because they do not perceive speaking as something that should be graded due to the fact that, in EFL classes in school, speaking is rarely assessed. Conversely, students who are eager to speak often have problems with formal evaluation, which rarely includes oral assessment. The results also show that students with lower grades and self-assessment are more selfconfident that they would do well on objective language tests, listen carefully to lectures on complex topics, get good grades and study enough to understand the material completely (items $4,7,10,11$ ). It is possible that they really want to experience progress, so they convince themselves they can perform well, which might lead to overestimating self-efficacy. In contrast, students who have good grades and self-evaluation are still not confident because they doubt other aspects of their learning or even their personality. Additionally, students with low selfevaluation are more likely to demand respect from the teacher (item 12), probably because they fear that their teachers would not respect them enough because of lower grades and lack of knowledge, so the students may try to overcome this problem by seeking respect in other ways such as standing up to them. The results of the grade and self-evaluation are very similar probably because students feel a grade truthfully reflects their actual knowledge and they adopt the same grade for 
self-assessment, even when they possess lesser or greater knowledge. It can be concluded that the impact of grades and self-evaluation can significantly change the degree of self-efficacy depending on the particular learning situation. Generally, high grades and self-assessment can lead to self-confidence, which enhances understanding and performance, but they are not always true indicators of students' knowledge and abilities and can lead to hindrance of self-esteem.

To sum up, all five factors have a powerful impact on students' academic self-efficacy, with self-evaluation being the most influential one. This is probably because the way learners evaluate themselves can be the most important influence on students since the way humans see themselves has a great influence on their thoughts, emotions and behaviours. Also, the independent use of English outside the classroom and the students' grade proved to be of great importance for selfefficacy since grades provide a very important measurement of knowledge and self-worth, as well as the ability to use the language independently and more freely. Nevertheless, the attendance of private English lessons and the age at which they started learning also produces significant influences on self-efficacy because of the time and additional effort put into language learning, as well as the exposure to a foreign language.

\section{CONCLUSION}

Our research was conducted with the aim of answering which learner characteristics have independent impact on students' academic self-efficacy. The data was gathered by a questionnaire distributed to grammar-school students in six classes ranging from the first to the fourth year of study. The results were interpreted by descriptive and inferential analysis of self-efficacy depending on each independent variable, determining that all independent variables were more or less influential, with the independent use of English outside the classroom, students' grade and self-evaluation as the most powerful determiners. Also, it was established that the average degree of academic self-efficacy in English is relatively high. However, students' self-efficacy should be further enhanced since they can benefit from it in terms of high motivation, low anxiety and successful academic performance. Therefore, the educational system in Serbia and all its teachers should work on ways to enhance students' self-efficacy, such as including all aspects of language into the curriculum, the classroom and the grading system, promoting stress-free environment, offering support, encouraging autonomy in language use, and ultimately teaching them to value their strengths. 


\section{REFERENCES}

Almarwaey, A. O. (2017). "Using Social-Networking Sites in Learning English Language and Students' Self-Efficacy". US-China Education Review A 7(5): 246-254.

Baleghizadeh, S. \& Masoun, A. (2014). "The Effect of Self-Assessment on EFL Learners' Self Efficacy” TESL Canada Journal 31(1): 42.

Bandura, A. (1982). "Self-efficacy mechanism in human agency". American Psychologist 37: 122-147.

Bandura, A. (1997). Self-efficacy: the exercise of control. New York: Freeman.

Bong, M. \& Skaalvik, E. M. (2003). "Academic Self-Concept and Self-Efficacy: How Different Are They Really"? Educational Psychology Review 15(1): $1-40$.

Bouffard-Bouchard, T., Parent, S., \& Larivee, S. (1991). "Influence of self-efficacy on self-regulation and performance among junior and senior high-school age students". International Journal of Behavioral Development 14: 153164.

Grusec, I.E. (1992). "Social learning theory and developmental psychology: The legacies of Robert Sears and Albert Bandura”. Developmental Psychology 28(5): 776-786.

Lampert, J. N. (2007). The Relationship of Self-Efficacy and Self-Concept to Academic Performance in a College Sample: Testing Competing Models and Measures. Master's thesis. Forest Grove, Oregon: Faculty of School of Professional Psychology Pacific University. Accessed on January 11, 2019. URL: <https://commons.pacificu.edu/cgi/viewcontent.cgi?article= $1140 \&$ context $=\mathrm{spp}>$

Montebon, D. R. T. (2016). "Shadow education: Effects on students' self-efficacy in science". International Journal of Research Studies in Education 5(1): 31-40.

Oscarson, M. (1997). "Self-assessment of foreign and second language proficiency", in Encyclopedia of language and education: Language testing and assessment, ed. C. Clapham \& D. Corson (Dordrecht, Netherlands: Kluwer Academic Publishers): 175-187.

Owen, S. V. \& Froman, R. D. (1988). "Development of a College Academic SelfEfficacy Scale". Accessed on January 17, 2019. URL: 〈https://files.eric.ed.gov/fulltext/ED298158.pdf >

Pajares, F. (1996). "Self-efficacy beliefs in achievement settings". Review of Educational Research 66: 543-578. 
Pajares, F. \& Schunk, D. H. (2001). "Self-Beliefs and School Success: SelfEfficacy, Self Concept, and School Achievement", in Self Perception, ed. R. J. Riding \& S. Stephen (Westport Ablex Publishing): 240-265.

Pajares, F. (2005). "Self-efficacy and adolescence: Implications for teachers and parents", in Adolescence and education, ed. F. Pajares \& T. Urdan (Greenwich, CT: IAP - Information Age Publishing): 339-367.

Pajares, F., \& Britner, S. (2006). "Sources of science self-efficacy beliefs of middle school students. Journal of Research in Science Teaching 43(5): 485-499.

Pajares, F., Johnson, M. J. \& Usher, E. L. (2007). "Sources of Writing SelfEfficacy Beliefs of Elementary, Middle, and High School Students". Research in the Teaching of English 42(1): 104-120.

Schunk, D. H. (1991). "Self-efficacy and academic motivation". Educational Psychologist 26: 207-231.

Schunk, D. H. \& Pajares, F. (2007). "The Development of Academic SelfEfficacy", in Development of achievement motivation, ed. A. Wigfield \& J. S. Eccles (Amsterdam: Elsevier): 15-32.

Tilfarlioğlu, F. T. \& Cg̉nkara, E. (2009). "Self- Efficacy in Efl: Differences among Proficiency Groups and Relationship with Success". Novitas-ROYAL 3(2): 129-142.

Wood, R. E. \& Locke, E. A. (1987). "The Relation of Self-Efficacy and Grade Goals to Academic Performance". Educational and Psychological Measurement 47: 1013-1024.

Staša V. Đokić

Univerzitet u Novom Sadu

Filozofski fakultet, Odsek za anglistiku

Miljana J. Cvjetićanin

Univerzitet u Novom Sadu

Filozofski fakultet, Odsek za anglistiku

\section{ANALIZA AKADEMSKE SAMOEFIKASNOSTI KOD UČENIKA KOJI UČE ENGLESKI JEZIK KAO STRANI JEZIK}

\section{Sažetak}

Cilj ovog istraživanja je da utvrdi koje karakteristike učenika imaju nezavistan uticaj na stepen akademske samoefikasnosti učenika koji uče engleski jezik kao strani jezik. Nezavisne varijable uključuju pohađanje privatnih časova engleskog jezika, samostalnu upotrebu engleskog jezika van učionice, uzrast od kog uče engleski jezik, ocenu iz engleskog jezika ostvarenu na kraju prethodnog polugodišta i samoprocenu znanja engleskog jezika. Podaci su prikupljeni pomoću upitnika koji su podeljeni u šest odeljenja u dve gimnazije, uključujući ispitanike od prve do četvrte godine gimnazije. Rezultati su 
analizirani i interpretirani korišćenjem deskriptivne i inferencijalne analize kako bi se analizirala samoefikasnost $u$ zavisnosti od svake nezavisne varijable. Deskriptivnom analizom prvo je utvrđeno da je sveukupna prosečna samoefikasnost relativno visoka $\mathrm{u}$ akademskom okruženju. Međutim, dalji porast i razvoj samoefikasnosti doprineo bi daljem povećanju motivacije, snižavanju anksioznosti i povećanju uspeha u akademskim zadacima. Pored toga, inferencijalnom analizom utvrđeno je da sve nezavisne varijable imaju veći ili manji uticaj na samoefikasnost, dok su samostalna upotreba engleskog jezika van učionice, ocena iz engleskog jezika ostvarena na kraju prethodnog polugodišta i samoprocena znanja engleskog jezika najznačajnije determinante akademske samoefikasnosti (s obzirom na to da je utvrđeno da su navedene varijable statistički veoma značajne). Uzimajući sve ovo u obzir, sistem školstva u Srbiji bi, zajedno sa nastavnicima i profesorima, trebalo da radi na pronalaženju načina kojima bi se povećala samoefikasnost učenika. Vrlo je važno da svi aspekti jezika biti uključeni u nastavni plan i program, kao i u rad na času i sistem ocenjivanja. Neophodno je težiti ostvarivanju prijateljske atmosfere na času, pružati podršku i razumevanje učenicima, ohrabrivati autonomiju učenika u korišćenju jezika, i naposletku, podučiti učenike kako da cene svoje sposobnosti, veštine i znanje.

Ključne reči: samoefikasnost, učenici koji uče engleski kao strani jezik, privatni časovi engleskog jezika, samostalna upotreba engleskog jezika, uzrast od kog se uči, ocena iz engleskog jezika, samoprocena znanja engleskog jezika. 


\section{APPENDIX}

\section{UPITNIK}

Pre nego što pređemo na glavni deo upitnika, molimo vas da popunite sledeće podatke. Podaci ostaju anonimni i nema potrebe da pišete svoje ime i prezime. Pol: M Z̆

Razred:

Od koje godine učite engleski jezik:

Da li i privatno učite engleski jezik (u školi stranih jezika ili na privatnim časovima)? DA NE

Da li koristite engleski samostalno van škole? DA NE

Koju ocenu iz engleskog ste imali na kraju prošle školske godine? 1223445 Koju ocenu mislite da bi trebalo da imate iz engleskog? $\begin{array}{lllll}1 & 2 & 3 & 4 & 5\end{array}$

U glavnom delu upitnika nalaze se tvrdnje koje se odnose na učenje engleskog jezika u školi. Molimo vas da odgovorite u kolikoj meri verujete da možete uspešno da izvršavate date aktivnosti na časovima engleskog jezika, tako što ćete za svaku tvrdnju zaokružiti jedan broj na skali od 1 do 5 .

1 - uopšte ne verujem

2 - pomalo verujem

3 - niti verujem niti ne verujem

$4-$ verujem

$5-\mathrm{u}$ potpunosti verujem

Verujem da uspešno mogu da:

1. zapisujem u toku časa i svoje beleške dobro organizujem

12345

2. učestvujem u diskusijama na času

12345

3. odgovaram na pitanja u velikim odeljenjima

12345

4. radim „objektivne" testove koji uključuju biranje tačnog od više ponuđenih odgovora, određivanje da li je tvrdnja tačna ili netačna, itd.

12345

5. radim testove sa esejskim pitanjima koji uključuju opširne i argumentovane odgovore na pitanja

12345

6. pišem seminarske radove i/ili prezentacije visokog kvaliteta

12345

7. pažljivo slušam na času kada se obrađuje kompleksna tema

12345

8. podučavam druge učenike 
12345

9. pitam profesora na času da ponovo objasni određeni deo gradiva koji nisam razumeo/la

12345

10. dobijam dobre ocene u većini slučajeva

12345

11. učim dovoljno kako bih razumeo/la gradivo u potpunosti

12345

12. tražim od profesora da me poštuje

123345

13. redovno prisustvujem časovima

12345

14. ubedim profesora da obraćam pažnju na gradivo tokom časa i kada nije tako 12345

15. razumem većinu gradiva koje se obrađuje na času

12345

16. razgovaram nasamo sa profesorom kako bih njega ili nju bolje upoznao/la

12345

17. povezujem gradivo iz engleskog sa gradivom iz drugih predmeta

12345

18. se otvoreno ne slažem sa mišljenjem profesora na času

12345

19. učim redovno, a ne ,kampanjski”, odnosno da ne učim gradivo samo par dana pred odgovaranje, kontrolni ili pismeni zadatak

12345

Received: 15 May 2019

Accepted: 11 September 2019 